\title{
FACTORS AFFECTING THE ORGANOCHLORINE POLLUTANT LOAD IN BIOTA OF A RICE FIELD ECOSYSTEM \\ (EBRO DELTA, NE SPAIN). \\ D. Pastor ${ }^{\mathrm{a}}$, C. Sanpera ${ }^{\mathrm{b}}$, J. González-Solís ${ }^{\mathrm{b}}$, X. Ruiz ${ }^{\mathrm{b}}$, J. Albaigés ${ }^{\mathrm{a}}$ \\ ${ }^{a}$ Department of Environmental Chemistry. CID-CSIC. J. Girona Salgado, 18-26. 08034-Barcelona, Spain \\ ${ }^{\mathrm{b}}$ Department of Animal Biology. Faculty of Biology. University of Barcelona. Diagonal, 645, 08028-Barcelona, Spain
}

\begin{abstract}
The concentrations of PCBs, DDTs, HCHs, HCB and OCS were determined in sediments and associated biota, both invertebrates (Physella acuta, Hirudo medicinalis, chironomid larvae, Hydrous pistaceus, Helochares lividus) and vertebrates (Rana perezi), in a temporary aquatic system, a rice field in the Ebro Delta (NE Spain). The qualitative and quantitative distribution of organochlorine compounds in sediments and aquatic biota has been explained by two mechanisms: equilibrium partitioning and/or biomagnification through the trophic web. Nevertheless, bioaccumulation processes are by far more complex, since several biotic and abiotic factors contribute to the observed pollutant loads in the organisms. In this respect, the biological characteristics of the organisms considered (e.g. species, age, lipid contents, feeding habits, etc.), as well as ecological factors (e.g. the habitat of the species and vertical distribution), have been shown to account for the organochlorine levels observed.
\end{abstract}

Key words: POPs, aquatic ecosystem, rice field, bioaccumulation, sediments, invertebrates, vertebrates.

*Corresponding author. Tel: +34-93-4006152. Fax: +34-93-2045904. E-mail: albqam@cid.csic.es 


\section{Introduction}

In the aquatic environment hydrophobic compounds, such as PCBs and DDTs, tend to be adsorbed onto particulate matter according to a simple partitioning process (Bierman, 1990). On the other hand, the main transfer pathways of these contaminants to aquatic organisms are controlled by an equilibrium partitioning between the external media (water or sediment) and the organism lipid fraction and/or by the food-web constraints (Farrington, 1991, MacDonald et al., 1993, Nowell et al., 1999). However, other factors such as the intrinsic characteristics of the organism biology, ecology or life-history traits as well as the environmental conditions may also affect the accumulation of organic contaminants by aquatic biota. Feeding behaviour, migration habits, breeding season, larval or post-metamorphic conditions, in addition to trophic level, age, or any other circumstances affecting exposure, mobility or changes in the lipid fraction of their bodies, can alter the final concentration of pollutants found in their tissues (Wiederholm, 1984, Barron, 1990, Clark et al., 1990, Cortet et al., 1999, Nowell et al., 1999).

Most of the field studies done until present regarding the compartmental distribution of pollutants in aquatic organisms have been largely focused, on the two aforementioned mechanisms, but the influence of many of such organism characteristics has not been yet properly assessed (see Nowell et al., 1999 for a review). Bierman (1990) has already suggested that ecological variables other than trophic level (biomagnification) should be considered to account for the accumulation of organic pollutants observed in sedimentdwelling organisms, which are actually much higher than those expected by equilibrium partitioning only. 
The aim of this paper has been to examine different abiotic and biotic factors influencing the organochlorine load of sediments and organisms, in a temporary aquatic ecosystem, the Ebro Delta rice fields (Northeast Spain).

Rice fields are dynamic systems of particular environmental concern because they exhibit a high capacity to concentrate and deliver pollutants. In fact, they receive large pesticide applications, they are also extensively irrigated with waters which may contain significant amounts of pollutants, and their sediments are periodically re-suspended, enhancing water-biota exchanges (Forés and Comin, 1991; Mañosa, 1997). In this respect, the bioaccumulation processes in shallow-water ecosystems have been found to be one order of magnitude higher than those occurring in deeper waters (MacDonald et al., 1993). On the other hand, rice fields are usually keystone environments for waterbirds; they host large amounts of prey which constitutes the bird's diet, and the pollutant levels could pose a risk for them directly, through poisoning, and indirectly through decline in preys availability (Fasola and Ruiz, 1995, Tourenq et al., 2001).

Previous studies carried out in the Ebro Delta rice fields (Figure 1) have already reported the accumulation of noticeable amounts of organic and inorganic pollutants, namely organochlorine compounds and heavy metals, in birds and other biota feedingon and/or living in the area (Llorente et al., 1987, Ruiz and Llorente, 1991, Porte et al., 1992, Ruiz et al., 1992, Morera et al., 1997, Ramos et al., 1999). Changes in the biodiversity of the rice field macrofauna attributed to the use of pesticides have also been recorded (Mañosa, 1997). Therefore, a complete understanding of the processes and mechanisms governing bioaccumulation in this singular temporary aquatic 
ecosystem is needed in order to prevent losses in wetland biodiversity and other threats concerning waterbird food-shortage and poisoning risks.

\section{Experimental}

\subsection{Organisms studied}

The organisms considered in the study and their ecological characteristics are summarized in Table 1.

Invertebrates .- Freshwater gastropods make up a large proportion of benthic animal biomass in variable aquatic habitats and may play a keystone role in the transfer of matter and energy in rice field ecosystems. In the Ebro Delta, Physella acuta is one of the most abundant bassommatophoran species. It seems to forage mainly on epiphytic vegetation and adventitious plants (González- Solis and Ruiz, 1996).

Among the Annelids, bloodsuckers (Cl. Hirudinea, Hirudo medicinalis) attain a high density in the Ebro delta rice fields and constitute a prey for Cattle Egrets (Ruiz, 1985). Chironomid (diptera) larvae and aquatic coleopterans (Fam. Hydrophilidae: Hydrous pistaceus, Helochares lividus) are among the main insect fauna in the rice field ecosystem. Chironomid larvae can be very abundant and constitute an essential link in the rice field trophic web since they are directly preyed by ducks and waders, and constitute also the main food supply for larger insects and crustaceans later taken by herons and egrets. Gonzalez-Solís et al. (1996) reported that ducklings consume chironomids as the main source of protein during growth. In the Ebro Delta, coleopterans (adult and larvae) are the main components of the insect community in terms of biomass . Arthropod preys have been registered in the diet of all the colonial 
herons breeding in this area and are the bulk of the biomass consumed by the Cattle egret (Gonzalez-Solís et al., 1996).

Vertebrates .- The green frog (Rana perezi) is the commonest amphibian species in the area. Their diet accommodate to changes produced by seasonal dynamics of the rice crop: during the dry period (January-April) terrestrial prey dominate the diet while flying (dipterans) prey are common during the flooding period (May-November) (Jover, 1989). Frogs are the staple food for Cattle egrets but they are also actively predated by other waterbirds (Mañosa, 1997).

\subsection{Sampling}

Surface sediments $(5 \mathrm{~cm}$ depth) were collected with a grab sampler, placed in glass jars and kept frozen $\left(-20^{\circ} \mathrm{C}\right)$ until analysis. Organisms were collected along a rice cultivation cycle, using a biocenometer device (a metallic square of $60 \mathrm{~cm}$ by side and $40 \mathrm{~cm}$ high) sunk at $5 \mathrm{~cm}$ depth in the paddy field soil. All the volume was filtered through a mesh sieve of $1.2 \mathrm{~mm}$, and the organisms were washed, classified and frozen until their analysis. Biocenometer sampling was conducted at five different locations within the area.

Because the size of most of the species collected was too small to provide a sample volume enough for the analysis at the individual level, composite samples including all the individuals from the same species were pooled for each sampling location $(n=5)$. 


\subsection{Analysis}

Sediments were freeze-dried, sieved at $1 \mathrm{~mm}$ to remove coarse sands and organic debris and Soxhlet extracted for $12 \mathrm{~h}$ with a mixture of $n$-hexane-dichloromethane (4:1). Biota tissues were dried at $50^{\circ} \mathrm{C}$ to constant weight to determine their water contents and extracted with $n$-hexane in a Soxhlet apparatus. The solvent extracts were fortified with octachloronaphthalene as internal standard, evaporated to near dryness, the residue dissolved in $3 \mathrm{ml}$ of $n$-hexane and cleaned-up by vigorous shaking with 1-2 $\mathrm{ml}$ of conc. $\mathrm{H}_{2} \mathrm{SO}_{4}$. The resultant extract was washed with water, dried over $\mathrm{Na}_{2} \mathrm{SO}_{4}$ and conveniently diluted with $\underline{n}$-hexane for GC-ECD analysis. An aliquot of the solvent extract was evaporated for the gravimetric determination of the sample fat contents.

The gas chromatograph (Hewlett-Packard Model 5890, Palo Alto, CA, USA) was equipped with an automatic injector (Hewlett-Packard Model 7673A) and a ${ }^{63} \mathrm{Ni}$ electron capture detector. The column, a 30 m DB-5 fused silica (J\&W Scientific, Folsom, CA, USA), was programmed from 60 to $300^{\circ} \mathrm{C}$ at $6^{\circ} \mathrm{C} \cdot \mathrm{min}^{-1}$, the final temperature being maintained for $10 \mathrm{~min}$. Helium was used as carrier gas. The injector and detector were set at $270{ }^{\circ} \mathrm{C}$ and $300{ }^{\circ} \mathrm{C}$, respectively.

Seven PCB congeners (IUPAC no. 28, 52, 101, 118, 138, 153 and 180, purchased from PROMOCHEM, Wesel, Germany) were selected for quantitative analysis of PCBs, following the criteria of International Monitoring Programs (Tuinstra et al., 1985). The analysis of DDT encompassed the determination of pp'-DDT, pp'-DDD and pp'-DDE by comparison with calibrated solutions of authentic standards as well as for the 
hexachlorocyclohexanes $(\alpha-\mathrm{HCH}$ and $\gamma-\mathrm{HCH})$, hexachlorobenzene (HCB) and octachlorostyrene (OCS), all them purchased from PROMOCHEM, Wesel, Germany. Rank order statistics for independent data, Kruskall-Wallis $\left(\chi_{\text {K-w }}^{2}\right)$ and Mann-Whitney $\left(\mathrm{W}_{\mathbf{M}-\mathbf{w}}\right)$ tests, were used to assess differences in total organochlorine concentration among groups of organisms. Sequential Bonferroni correction was applied in pairwise comparisons to ensure that overall alfa error was maintained at desired 0.05 .

\section{Results}

Concentrations of organochlorines in the rice field sediment and biota are given in Table 2, both in dry weight and in fat basis (ng. $\mathrm{g}^{-1} \mathrm{dw}$ ). Significant differences in total organochlorine concentrations were found among organisms $\left(\chi_{\mathrm{K}-\mathrm{W}}^{2}=23.7\right.$; d.f. $=8$; $\mathrm{p}<0.01$ ). The lower concentrations were generally found in the imago of Hydrous pistaceus, an aquatic herbivore. For OCS, the levels in sediments were relatively higher than those shown by some organisms, as it is the case for H. pistaceus and H. lividus. The imago of H. lividus showed the highest organochlorine levels, excluding OCS.

Filter-feeders organisms, midges (chironomidae larvae) and tadpoles of Rana perezi, did not show statistically significant differences in total organochlorine concentrations (fat and d.w.: $\mathrm{W}_{\mathrm{M}-\mathrm{W}}=18$; n.s.). Amongst the herbivores, $P$. acuta showed levels higher than those of $H$. pistaceus, both in fat and dry weight basis (fat: $\mathrm{W}_{\mathrm{M}-\mathrm{W}}=15 ; \mathrm{p}<0.05$; d.w.: $\left.\mathrm{W}_{\mathrm{M}-\mathrm{W}}=15 ; \mathrm{p}<0.05\right)$. Carnivore and detritivore organisms usually reached to higher accumulation levels (Figure 2), although differences can be observed according to the family of compounds considered. DDTs and PCBs predominate in all species and they represent more than $75 \%$ of the total compounds found (Figure 3). In general, DDTs are 
by large the predominant components, although insect species (chironomid larvae and H. pistaceus and H. lividus) exhibit a relatively higher proportion of PCBs.

The distribution of the different DDT metabolites (pp'-DDT, pp'-DDD and pp'-DDE) is shown in Figure 4. pp'-DDT represented only about 7\% of DDTs in sediments, which also contained the higher proportion of pp'-DDD. These percentages were lower in biota, except in the larvae of $H$. pistaceous. pp'-DDT was even not detected in many of them, but the relative amount of pp'-DDD was higher in snails and tadpoles.

The distributions of PCBs were also assessed according to the level of chlorination (Figure 5). The different congeners were assembled in two groups, namely with low (3, 4 and 5 chlorines, hereafter LC PCBs) and high degree of chlorination (6 and 7 chlorines, hereafter HC PCBs). Seventy-five percent of total PCBs in sediments corresponded to hexa- and hepta-chlorinated congeners. The organisms did not show a clear distribution pattern. While HC PCBs predominate in H. lividus and P. acuta, a greater proportion of lower chlorine congeners were found in the larva of $H$. pistaceus and in the tadpoles of Rana perezi.

When comparing adults and larvae of the same species the following differences were found. In general, a relative and concomitant increase of pp'-DDE at the expenses of pp'-DDT was observed in passing from larval to adult forms. The percentage of DDE was higher in the adults of the green frog than in the tadpoles $\left(\mathrm{W}_{\mathrm{M}-\mathrm{W}}=16 ; \mathrm{p}<0.05\right)$. On the other hand, the ratio $\mathrm{LC} / \mathrm{HC}$ PCBs was significantly higher in larvae than in adults $\left(\mathrm{W}_{\mathrm{M}-\mathrm{W}}=15 ; \mathrm{p}<0.05\right)$. 
The larva of $H$. pistaceus showed higher total organochlorine levels than the imago of the same species $\left(\mathrm{W}_{\mathrm{M}-\mathrm{W}}=15 ; \mathrm{p}<0.05 ; \mathrm{d} . \mathrm{w}\right.$. and fat basis $)$. However, no significant differences were found between the larval form and the imago of $H$. lividus $\left(\mathrm{W}_{\mathrm{M}-\mathrm{W}}=24\right.$; n.s; d.w. and fat basis), which showed a very high predominance of the HC PCBs.

\section{Discussion}

The chlorinated compounds found in the rice fields of the Ebro Delta are the result of the agricultural activities as well as of their past industrial production upstream of the river (Cid et al., 1990). At present, all these compounds are banned, so that their presence reflects their long persistence in the aquatic environment. Particularly noticeable is the occurrence of OCS, rarely described in the literature and originated as a sub-product in the chloro-alkali processes (Ernst et al., 1984; Kaminsky and Hites, 1984). Such a factory is located $200 \mathrm{~km}$ upstream the Ebro River.

These pollutants can be distributed among the three main compartments, namely water, sediment and biota, according to partitioning models (Carey et al., 1998). These models have been effective in estimating the distribution of hydrophobic pollutants between water and sediments and the bioaccumulation potential in aquatic biota, especially fish and benthic invertebrates. Although sediments constitute a sink, these pollutants can be made available to biota by desorption processes to water, by contact with the organism body surface(s) and/or by bioturbation, thus enhancing the ingestion of re-suspended particles (Schaw and Connell, 1986, Nowell et al., 1999).

According to the equilibrium partitioning hypothesis, the bioaccumulation depends on the affinity of the chemical for the tissues of the organisms and thus, the levels of 
persistent pollutants should not present large differences amongst the organisms analysed if results are referred to fat content (Van der Oost et al., 1988). On the other hand, it has been generally stated that biomagnification plays an important role in the bioaccumulation processes (Bierman, 1990; Lake et al., 1990, MacDonald et al., 1993). However, a detailed assessment of the results shown in Table 2 indicate that bioaccumulation is also greatly influenced by other aspects, such as the biological or ecological characteristics of the organisms examined.

In this regard, the ratio of DDT metabolites over total DDTs (DDT+DDE+DDD) has been used as an estimate of the time elapsed since the use of the pesticide. The proportion of pp'-DDT in the samples analysed (Figure 4) suggests that historical inputs are the main source of DDTs in this ecosystem. Nevertheless, the relatively high proportion of pp'-DDT (ca. 12\%) in the larva of Hydrous pistaceus is difficult to explain, since it has no parallel in other organisms with analogous biology and ecology. The lack of metabolic systems for this compound or selective processes of uptake, could be among the possible causes. It is worth pointing out that the ability to accumulate pp'DDT would give this species an excellent role as sentinel in the environmental assessment of this pesticide.

Interestingly, those organisms known to be highly resistant to pp'-DDT, such as $H$. medicinalis (Sawyer, 1974) or P. acuta (Harman, 1974), do not show detectable levels of that contaminant. In Hirudo medicinalis and in the imago and larval forms of Helochares lividus, the high levels of DDTs are accompanied by an increase in pp'DDE, thus constituting an additional risk for their vertebrate predators. 
Most vertebrates can metabolise DDT owing to the presence of hepatic MFO systems (Carey et al., 1998). Their capacity is well in agreement with general metabolic rate (small vertebrates higher than large ones), directly related to variability of ingested food (omnivorous and herbivorous higher than carnivorous) and to some extent, also determined by phylogenetic constraints (higher in mammals than in birds and fish) (Walker, 1980). In Rana perezi changes associated to metamorphosis can explain intraspecific differences in DDT metabolites, as it occurs with dieldrin (Cooke, 1979, Schuytema et al., 1991), since microsomal enzymatic systems might be less functional in tadpoles and detoxification capacities seems to develop as the larva grows up thus explaining the higher percentage of DDE found in the adults.

DDD is mainly produced in anoxic sediments (Zoro et al., 1974) and its abundance in the sediments of the rice field reveals the reductive condition of this compartment. Thus, the ratio DDD/DDE can be related to the benthic habits of the organisms studied, especially in those also feeding in the sediment fraction. In the tadpoles, the value DDD/DDE is very close to that of the sediment (0.9 to 1.2$)$. Similarly, organisms such as $P$. acuta which move over the rice field bottom, bioturbate the sediment and this would allow a higher DDD availability. On the other hand, organisms living in the water column (both imago and larva of Hydrous pistaceus and Helochares lividus) show mean ratio values around 0.3 .

The case of midges, which are also filter-feeders, do not show detectable amounts of DDD. This is particularly interesting because they feed on particles suspended in the water column, prior to reaching the anoxic environment, i.e. before DDD synthesis occur. The values for metamorphosed Rana perezi are very low, perhaps because of the 
nectonic habits of the adults, in addition to the increased detoxification capacities mentioned above.

As far as the transfer of PCBs to biota, LC PCB present a higher solubility and are associated mainly to the water dissolved phase, whereas HC PCB tend to be more associated to particulate matter, both in the water fraction and in the sediment (Valls et al., 1990), thus being prone to biomagnification through the food web.

Two groups of organisms can be identified according to the prevalence of one or another PCB congeners pattern, namely those presenting a large predominance $(>80 \%)$ of HC PCB congeners (Physella acuta, Chironomidae, and Helochares lividus, both larva and imago), and those having noticeable amounts (>40\%) of LC PCB congeners (Hydrous pistaceus, larva, Rana perezi, larva and Hirudo medicinalis) (Figure 5). In H. lividus, both larval and imago stages are the organisms showing the higher organochlorine levels and also the high percentages of HC PCBs, thus fitting well the biomagnification model. However, it must be pointed out that the LC PCB group includes a predator form, such as $H$. pistaceus larva, whereas some non-predator animals, like the mollusc P. acuta, are placed in the HC PCB group. This would indicate that additional considerations other than trophic level are needed to explain the observed PCB congener bioaccumulation profiles. Moreover, the lower PCB levels in frogs would suggest the action of enzymatic detoxification systems. In midges, which are filter-feeders, most PCBs corresponded to HC PCB (ca. 96\%), suggesting that the source of these compounds is the particulate matter they ingest in the water column and that adsorption rates discriminating LC from $\mathrm{HC}$ PCBs takes place before these compounds reach the sediment. 
The case of Rana perezi is especially significant because the transition from the tadpole to the adult is accompanied mainly by a qualitative change in the PCB profile. If a greater proportion of LC PCBs is to be found in solution into the aqueous phase, it is expected that the relative abundance of these congeners will be higher in those organisms showing filter-feeding habits or being gill-breathers which circulates high volumes of water through the body, as is the case with $R$. perezi or H. pistaceus larvae. Conversely, the percentage of LC PCBs would be lower in the adult stages of these organisms, which are air-breathers, as it is the case (LC PCBs, ca.25\%). The fact that metamorphosis in both species is associated to a change in diet, from predator to herbivore in $H$. pistaceus, and from microphagous to carnivorous in $R$. perezi, put forward that trophic level is not always the main factor governing the pattern of PCB congener distribution.

The pattern observed for PCBs in bloodsuckers (H. medicinalis) is in agreement with that of $R$. perezi, since the higher degree of LC PCB must be presumably in correspondence with the levels present in the host's blood, HC PCBs being effectively retained in tissues of higher fat content.

In conclusion, the study clearly indicates that the organochlorine biomagnification according to the trophic level in ecosystems is not a general trend. Actually, it is only observed in particular circumstances. Other biological and ecological factors may play a major part and may lead to higher contamination in invertebrates that in vertebrates. The lack of relationship between the contamination level and the trophic level is emphasized by similar results from other environments and ecosystems (Nowell et al., 1999). 


\section{Acknowledgements}

Thanks are given to Lluis Jover for his critical review of the manuscript and helpful comments .

\section{References}

Barron, M.G., 1990. Bioconcentration. Environ. Sci. Technol., 24, 1612-1618.

Bierman, V.J., 1990. Equilibrium partitioning and biomagnification of organic chemicals in benthic animals. Environ. Sci. Technol., 24, 1407-1412.

Carey, J., Cook, J., Giesy, J., Hodson, P., Muir, D., Owens, W. and Solomon, K., 1998. Ecotoxicological Risk Assessment of the Chlorinated Organic Chemicals. SETAC, Pensacola, FL.

Cid, J.F., Risebrough, R.W., de Lappe, B.W., Mariño, M.G. and Albaigés, J., 1990. Estimated inputs of organochlorines from the river Ebro into the northwestern Mediterranean. Mar. Poll. Bull., 21, 518- 523.

Clark, T., Clark, K., Paterson, S., Mackay, D. and Norstrom, R.J., 1990. Wildlife monitoring, modeling and fugacity. Environ. Sci. Technol., 22, 120-127.

Cooke, A.J.,1979. The influence of rearing density on the subsequent response to DDT dosing for tadpoles of the frog Rana temporaria. Bull. Environ. Contam. Toxicol., 21, 837-841.

Cortet, J., Gomot-De Vaufleury, A., Poinsot-Balaguer, A., Gomot, A., Texier, C. and Cluzeau, D., 1999. The use of invertebrate soil fauna in monitoring pollutant effects. European J. Soil Biol., 35, 115-134.

Ernst, W., Weigelt, V. and Weber, K., 1984. Octachlorostyrene. A permanent micropollutant in the North Sea. Chemosphere, 13, 161-168. 
Farrington, J.W., 1991. Biogeochemical processes governing exposure and uptake of organic pollutant compounds in aquatic organisms. Environ. Health Persp., 90, $75-84$.

Fasola, M. and Ruiz, X., 1995. The values of ricefileds as substitutes of natural wetlands for waterbirds in the Mediterranean region. Colonial Waterbirds, 19, $122-128$.

Forés, E. and Comín, F.A., 1991. Rice water column sediment relationship in rice fields. Vehr. Internat. Verein. Limnol., 24, 1560-1563.

González-Solís, J. and Ruiz X., 1996. Succession and secondary production of gastropods in the Ebro Delta rice fields. Hydrobiologia, 337, 85-92.

González-Solís, J., Bernadí X. and Ruiz X., 1996. Seasonal variation of waterbird prey in the Ebro Delta rice fields. Colonial Waterbirds, 19, 135-142.

Harman, W.N., 1974. Bloodsuckers (Annelida: Hirudinea). In: Hart, C.W., Fuller, S.H. (Eds.). Pollution ecology of freshwater invertebrates. Academic Press, NY

Hebert, C.E., Weseloh, D.V., Kot, L. and Glooschenko, V., 1994. Organochlorine contaminant in a terrestrial food-web on the Niagara, Pensilvannia, Ontario, Canada 1987-1989. Arch. Environ. Toxicol. Chem., 26, 356- 366.

Jover, L., 1989. Nuevas aportaciones a la tipificación trófica poblacional: el caso de Rana perezi en el Delta del Ebro. PhD Thesis. University of Barcelona.

Kaminsky, R. and Hites, R.A., 1984. Octachlorostyrene in Lake Ontario: Sources and fates. Environ. Sci. Technol., 18, 275-279.

Lake, J.L., Rubinstein, N.I., Lee II, H., Lake, C.A., Heltshe, J. and Pavignano, S., 1990. Equilibrium partitioning and bioaccumulation of sediment associated contaminants by infaunal organisms. Environ. Toxicol. Chem., 9, 1095- 1106. 
Llorente, G.A., Farran, A., Ruiz, X. and Albaigés, J., 1987. Accumulation and distribution of hydrocarbons, PCBs and DDT in tissues of three species of Anatidae from the Ebro Delta (Spain). Arch. Environ. Contam. Toxicol., 16, $563-572$

MacDonald, C.R., Metcalfe, C.D., Balch, G.C and Metcalfe, T.L., 1993. Distribution of PCB congeners in seven lake systems: interactions between sediment and foodweb transport. Environ. Toxicol. Chem., 12, 1991- 2003.

Mañosa, S., 1997. A review on rice farming and waterbird conservation in three western Mediterranean areas: the Camargue, the Ebro Delta, and the north-western Po Plain. Station Biologique La Tour du Valat Internal Report, 142 pp.

Morera, M., Sanpera, C., Crespo, S., Jover, L. and Ruiz, X., 1997. Inter- and intraclutch variability in heavy metals and selenium levels in Audouin's gull eggs from the Ebro Delta, Spain. Arch. Environ. Contam. Toxicol., 33, 71- 75.

Nowell, L.H., Capel, P.D. and Dileanis, P.D., 1999. Pesticides in the Hydrologic System, vol. 4. Pesticides in stream sediment and aquatic biota: distribution, trends, and governing factors. Lewis Publishers, CRC Press, Boca Raton, FL

Porte, C., Barceló, D. and Albaigés, J., 1992. Monitoring of organophosphorus and organochlorinated compounds in a rice crop field (Ebro Delta, Spain). Chemosphere, 24, 735- 743.

Ramos, L., Fernández, M.A., González, M.J. and Hernández, L.M., 1999. Heavy metal pollution in water, sediment and earthworms from the Ebro river, Spain. Bull. Environ. Contam. Toxicol., 63, 305- 311.

Ruiz, X., 1985. An analysis of the diet of Cattle Egrets in the Ebro Delta, Spain. Ardea, $73,49-60$. 
Ruiz, X. and Llorente, G.A., 1991. Seasonal variation of DDT and PCB accumulation in muscle of carp (Cyprinus carpio) and eels (Anguilla anguilla) from the Ebro Delta, Spain. Ardea, 73, 49- 60.

Ruiz, X., Petriz, J. and Jover, L., 1992. PCB and DDT contamination of heron eggs in the Ebro Delta, Spain. In: Finlayson, M., Hollis, T., Davis, T. (Eds.). Managing Mediterranean wetlands and their birds. IWRB, Special Publication no. 20. pp $115-117$.

Sawyer, R.T., 1974. Snails (Mollusca: Gasteropoda). In: Hart, C.W., Fuller, S.H. (Eds.). Pollution ecology of freshwater invertebrates. Academic Press, NY.

Schaw, G.R. and Connell, D.W., 1986. Factors controlling bioaccumulation of PCBs. In: Waid, J.S. (Ed). PCBs and the Environment. Vol I. CRC Press, Boca Raton, FL. pp 121-131

Schuytema, G.S., Nebeker, A.V., Griffis, W.L. and Wilson, K.N., 1991. Teratogenesis, Toxicity, and Bioconcentration in Frogs Exposed to Dieldrin. Arch. Environ. Contam. Toxicol., 21, 332-350

Tourenq, C., Bennetts, R.E., Kowalski, H., Vialet, M., Lucchesi, J-L., Kayser, Y. and Isenmann, P., 2001. Are rice fields a good alternative to natural marshes for waterbird communities in the Camargue, southern France?. Biol. Conserv., 100, $335-343$

Tuinstra, L.G.M, Ross, A.H., Griepink, B. and Wells, D.E., 1985. Interlaboratoty studies on the determination of selected chlorobiphenyl congeners with capillary gas chromatography using splitless- and on-column injection techniques. J. High Resol. Chrom. and Chrom. Comm., 8, 475- 480. 
Valls, M., Bayona, J.M., and Albaigés, J., 1990. Broad spectrum analysis of ionic and non-ionic organic contaminants in urban wastewaters and coastal receiving aquatic systems. Intern. J. Environ. Anal. Chem., 39, 329-348.

Van der Oost, R., Heida, H. and Opperhuizen, A., 1988. Polychlorinated biphenyl congener in sediment, plankton, mollusc, crustaceans and indicator organisms in bioaccumulation studies. Arch. Environ. Contam. Toxicol., 17, 721- 729.

Walker, C.H., 1980. Species variation in some hepatic microsomal enzymes that metabolize xenobiotics. Prog. Drug Metab., 5, 113-165.

Wiederholm, T., 1984. Responses of aquatic insects to environmental pollution. In : Resh, V.H., Rosenberg. D.M. (Eds.). The ecology of aquatic insects. Praeger Publ., NY. pp 508-557.

Zoro, J.A., Hunter, J.M., Eglinton, G., Ware, G.C., 1974. Degradation of $p p$ '-DDT in reducing environments. Nature, 247, 235-237. 


\section{$\underline{\text { FIGURE CAPTIONS }}$}

Figure 1.- Ebro Delta (NE Spain). * Sampling area.

Figure 2.- Boxplot of total organochlorines (log-concentration) in sediments and in different trophic categories (Filter-feeders: chironomids and tadpoles Rana perezi; Primary consumers: Physella acuta, Hydrous pistaceus; Secondary consumers: Hirudo medicinalis, Helochares lividus adult and larvae, Hydrous pistaceus larvae, Rana perezi)

Figure 3.- Percentage of different organochlorine levels in sediments and organisms from the rice fields $(\mathrm{L}=$ larvae $)$.

Figure 4.- Percentage of different DDT metabolites (pp'-DDT, pp'-DDD and pp'DDE) in sediments and organisms from the rice fields ( $\mathrm{L}=$ larvae).

Figure 5.- Percentage of HC PCBs congeners (6 and 7 chlorine atoms) and LC PCBs ( 3,4 and 5 chlorine atoms) in sediments and biota from the rice fields ( $\mathrm{L}=$ larvae). 
Figure 1

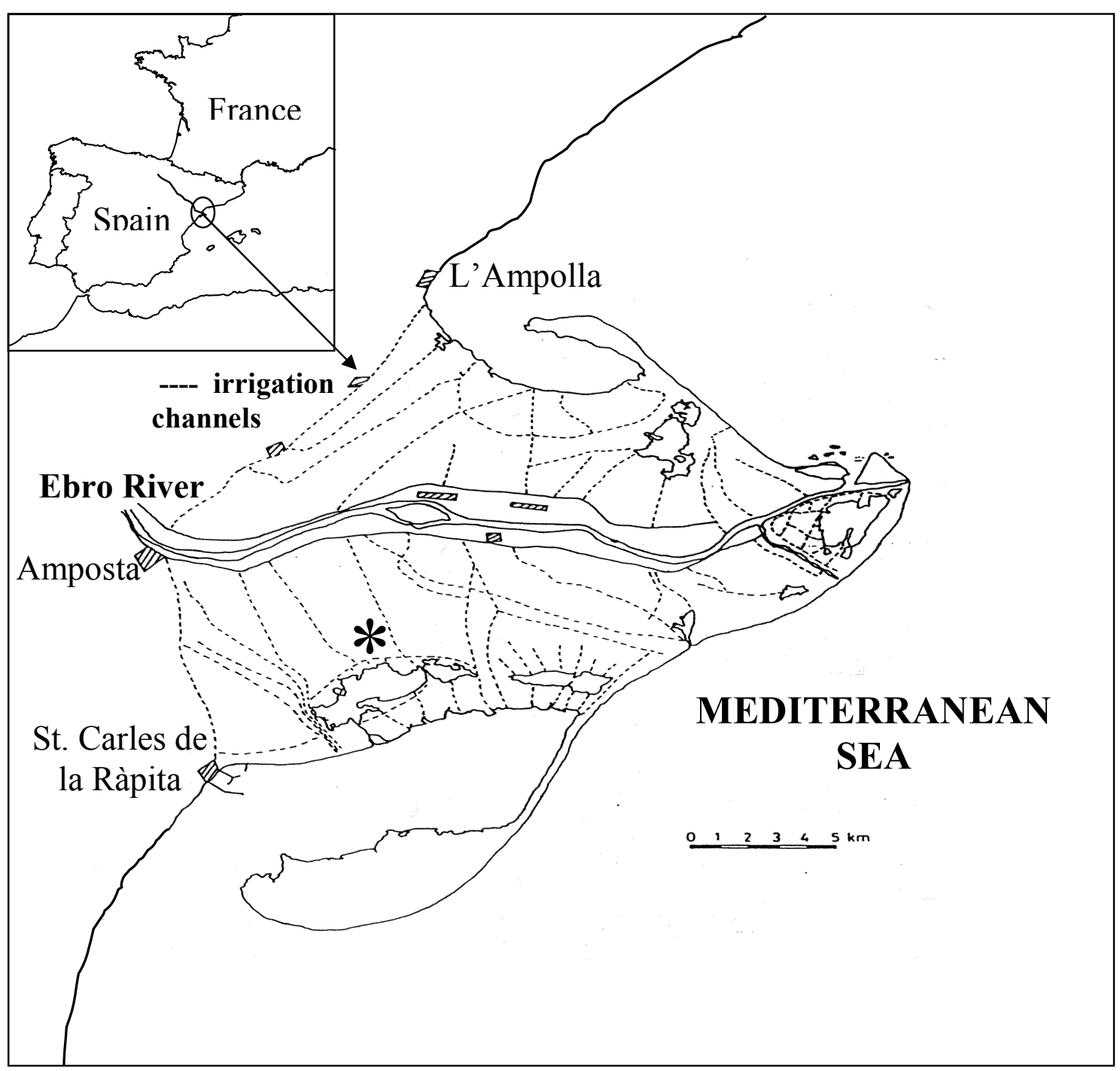


Figure 2

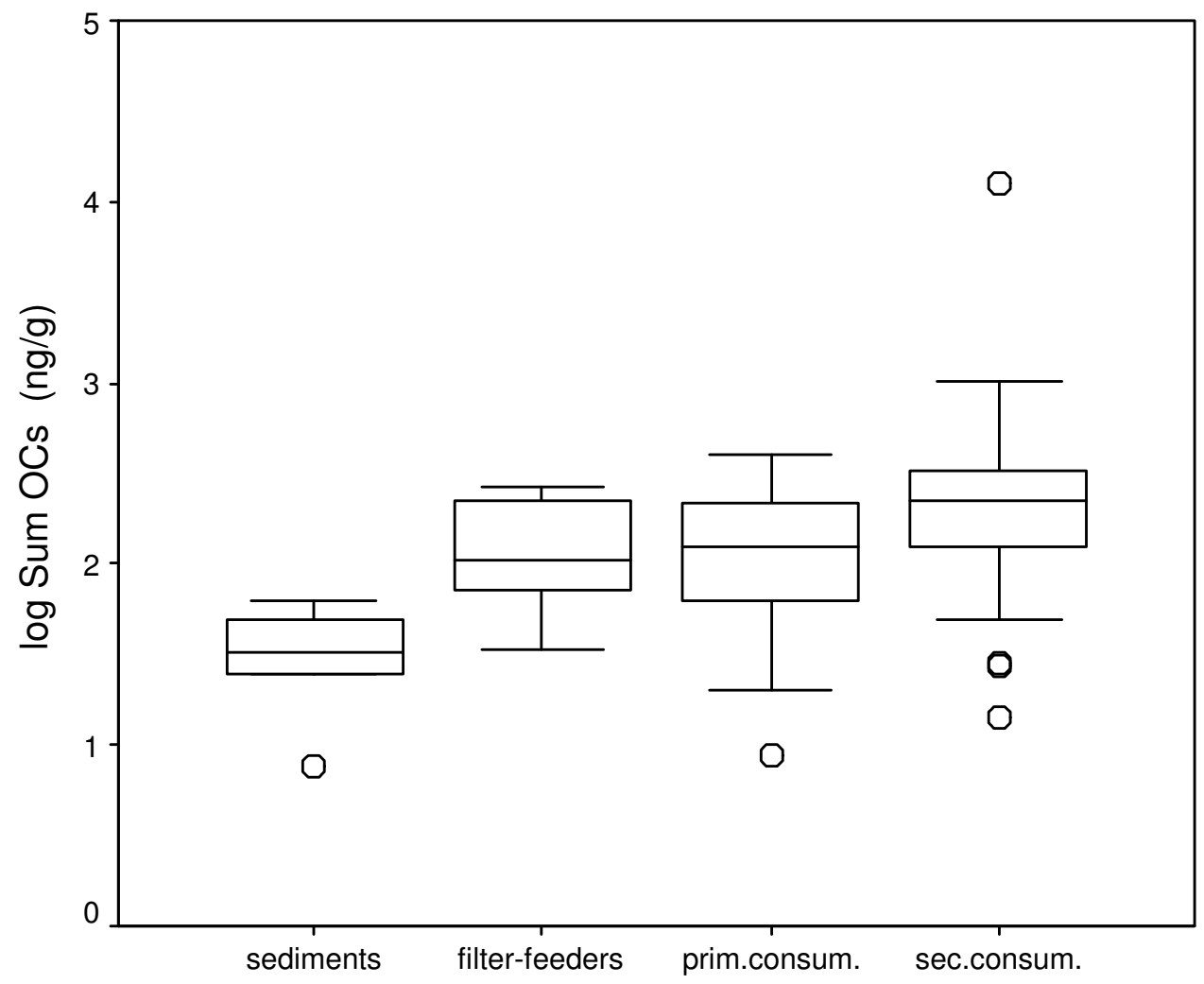


Figure 3

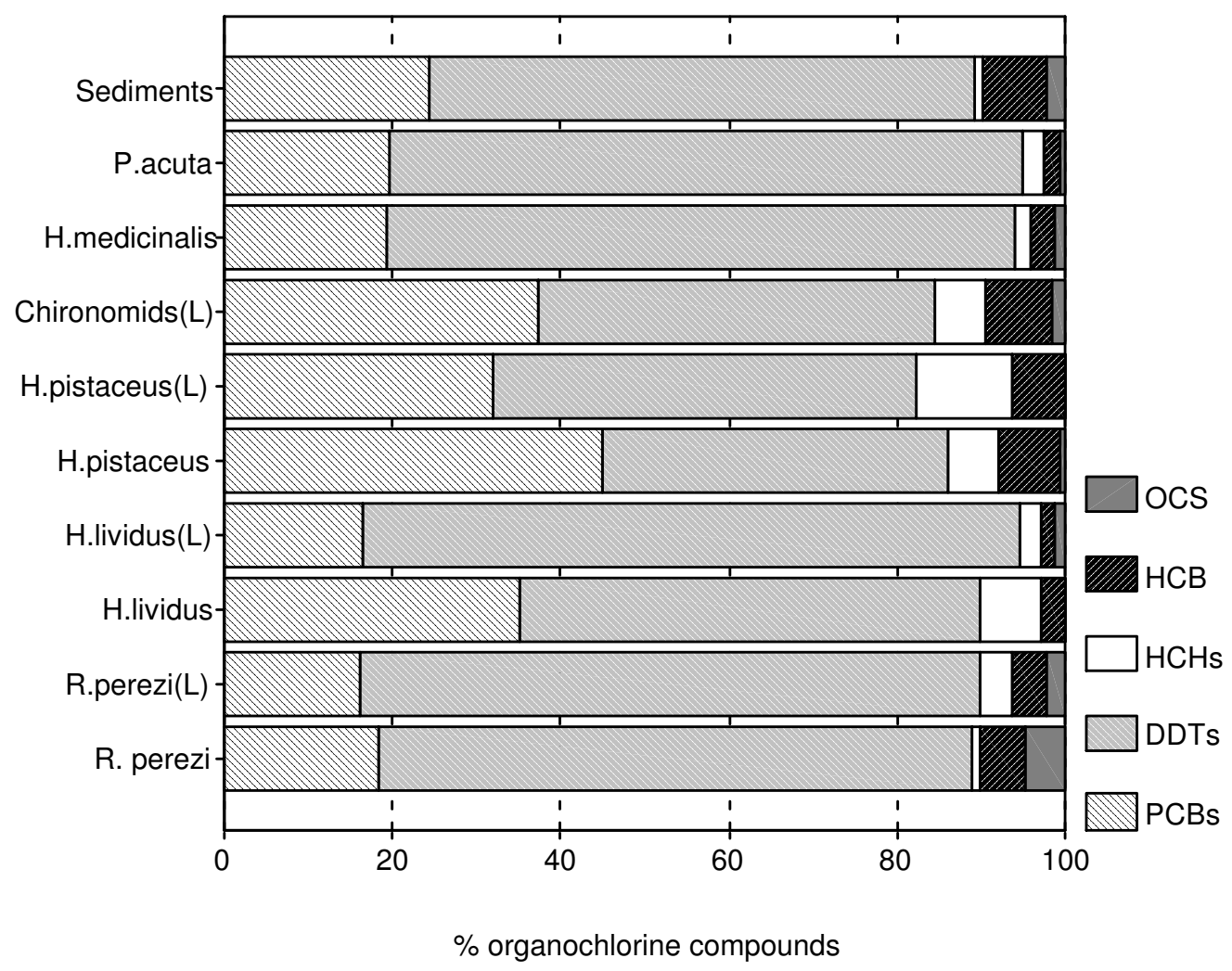


Figure 4

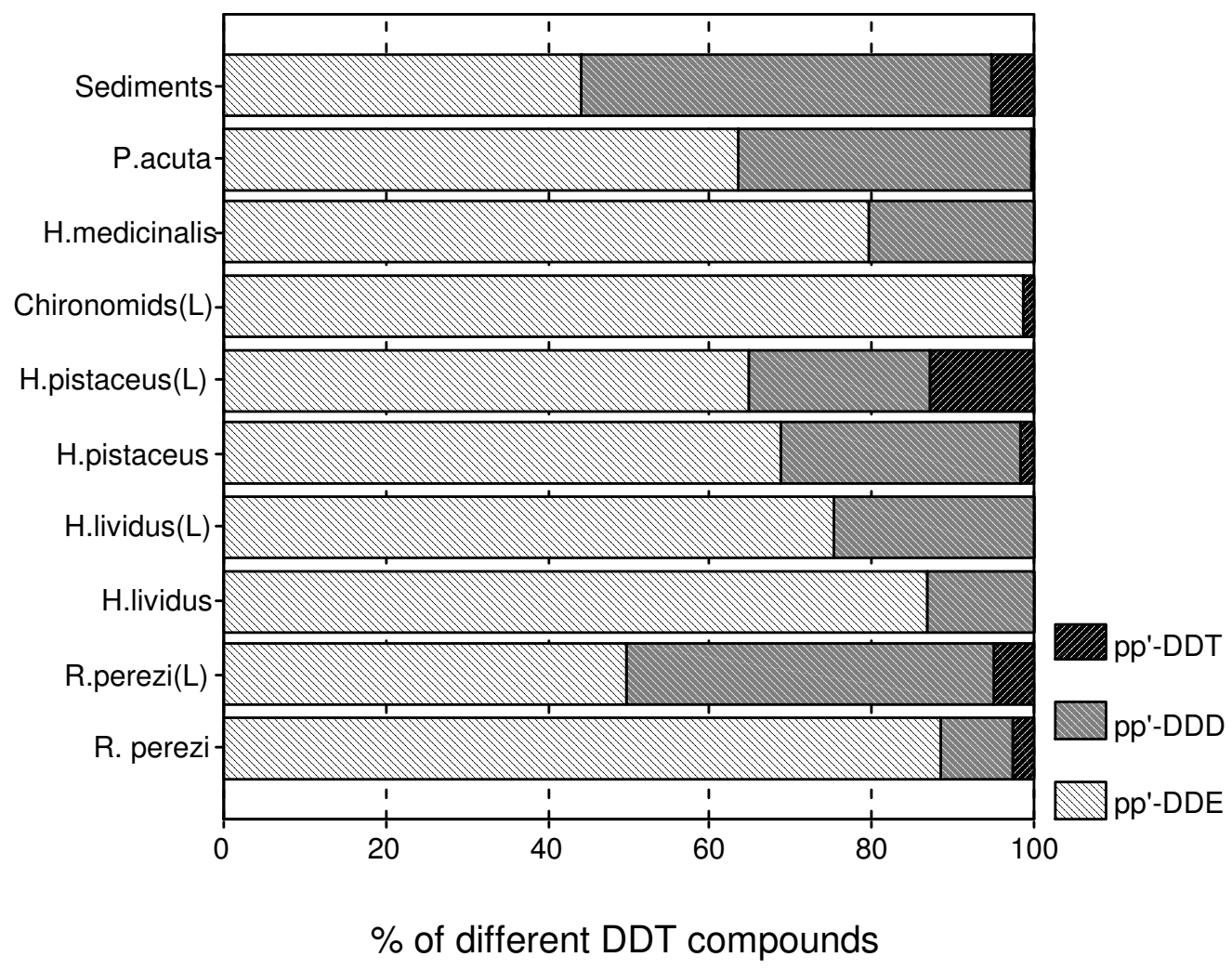


Figure 5

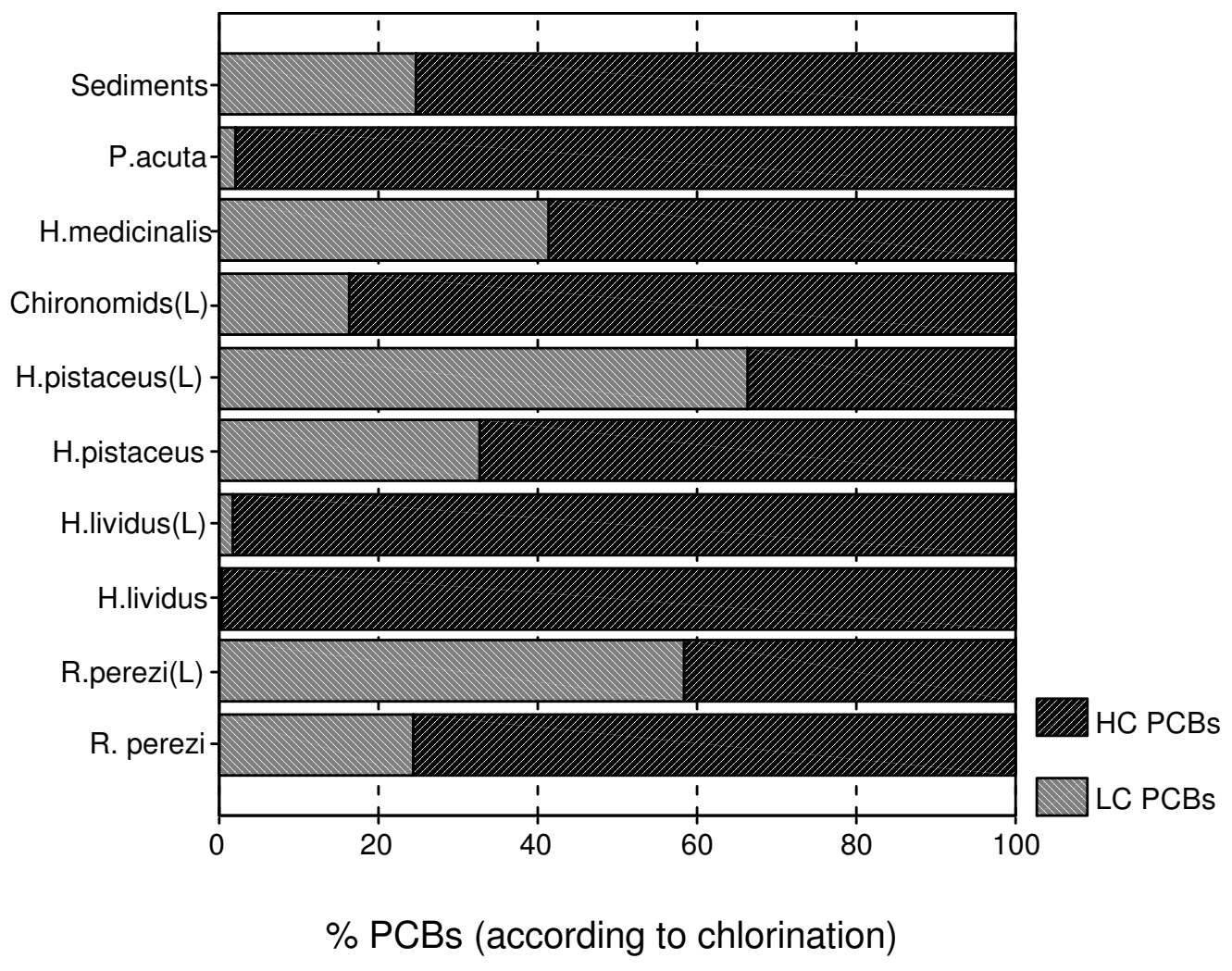


Table 1. Main ecological characteristics of the rice field organisms analysed.

\begin{tabular}{|c|c|c|c|}
\hline ORGANISMS & HABITAT & FEEDING & PREYED BY \\
\hline $\begin{array}{l}\text { Mollusca: } \\
\text { Physella acuta }\end{array}$ & Sediment-dwelling & Herbivorous & Ducks \\
\hline $\begin{array}{l}\text { Annelida: } \\
\text { Hirudo medicinalis }\end{array}$ & $\begin{array}{l}\text { Parasitic, mainly on } \\
\text { frogs }\end{array}$ & Vertebrate blood & Waterbirds \\
\hline Insecta: & Anoxic waters & $\begin{array}{l}\text { Periphyton, phytoplankton } \\
\text { filter-feeding }\end{array}$ & \\
\hline Hydrous pistaceus & Aquatic & $\begin{array}{l}\text { Larva: carnivorous } \\
\text { Adult: herbivorous }\end{array}$ & $\begin{array}{l}\text { Duck chicks, } \\
\text { mosquito-fish, } \\
\text { Ardeidae }\end{array}$ \\
\hline Helochares lividus & Aquatic & $\begin{array}{l}\text { Larva and adult: } \\
\text { Detritus-feeder, scavenger }\end{array}$ & \\
\hline Amphibia: & Aquatic & $\begin{array}{l}\text { Larva: sediment filter feeder } \\
\text { Adult: Insects and mollusca }\end{array}$ & Ardeidae \\
\hline
\end{tabular}


Table 2. Geometric mean of organochlorine compounds analysed in rice field organisms. Results are provided in ng. $\mathrm{g}^{-1}$ dry weight basis (a) and in fat basis (b).

$2 \mathrm{a}$.

\begin{tabular}{|c|c|c|c|c|c|c|c|}
\hline & & PCBs & DDTs & HCHs & HCB & OCS & DDTs/PCBs \\
\hline \multirow[t]{3}{*}{ Sediment } & G.M. & 5.9 & 15.7 & 0.2 & 1.8 & 0.6 & 2.7 \\
\hline & Min & 1.5 & 5.8 & $<0.1$ & 0.2 & 0.1 & 0.8 \\
\hline & Max & 10.6 & 55.0 & 2.8 & 11.9 & 2.8 & 10.3 \\
\hline \multirow[t]{3}{*}{ P.acuta } & $\overline{\text { G.M }}$ & 43.1 & 164 & 5.9 & 3.9 & 1.5 & 3.8 \\
\hline & Min & 19.5 & 119 & 3.2 & 1.8 & 0.0 & 1.7 \\
\hline & Max & 127 & 213 & 9.4 & 17.9 & 38.3 & 9.2 \\
\hline \multirow[t]{3}{*}{ H.medicinalis } & $\overline{\text { G.M. }}$ & 29.6 & 114 & 2.7 & 4.2 & 2.1 & 3.8 \\
\hline & Min & 3.4 & 8.6 & 1.3 & 0.6 & 0.1 & 1.4 \\
\hline & Max & 77.4 & 440 & 28.2 & 30.4 & 16.5 & 7.1 \\
\hline \multirow[t]{3}{*}{ Chironomid $(L)$} & G.M. & 53.8 & 67.8 & 8.8 & 11.3 & 2.2 & 1.3 \\
\hline & Min & 26.2 & 35.6 & 6.5 & 3.0 & 0.0 & 0.7 \\
\hline & Max & 107 & 138 & 10.9 & 46.1 & 30.1 & 2.4 \\
\hline \multirow[t]{3}{*}{ H.pistaceus (L) } & G.M. & 55.7 & 87.6 & 19.8 & 11.0 & 0.1 & 1.6 \\
\hline & Min & 25.2 & 40.5 & 2.3 & 7.3 & 0.0 & 0.6 \\
\hline & Max & 81.4 & 115 & 45.9 & 17.4 & 2.8 & 4.2 \\
\hline \multirow[t]{3}{*}{ H.pistaceus } & G.M. & 16.0 & 14.6 & 2.1 & 2.6 & 0.2 & 0.9 \\
\hline & Min & 4.5 & 3.1 & 0.7 & 0.5 & 0.0 & 0.6 \\
\hline & Max & 54.7 & 46.0 & 5.2 & 14.3 & 1.1 & 3.5 \\
\hline \multirow[t]{3}{*}{ H.lividus (L) } & $\overline{\text { G.M. }}$ & 43.0 & 206 & 6.5 & 4.7 & 3.1 & 4.8 \\
\hline & Min & 23.0 & 136 & 3.7 & 2.2 & 0.8 & 1.2 \\
\hline & Max & 111 & 286 & 10.2 & 12.0 & 9.9 & 12.4 \\
\hline \multirow[t]{3}{*}{ H.lividus } & G.M. & 170 & 265 & 36.0 & 12.9 & 0.2 & 1.5 \\
\hline & Min & 15.6 & 41.9 & 6.9 & 1.9 & $<0.1$ & 0.1 \\
\hline & Max & 945 & 10750 & 221 & 452 & 97.7 & 11.4 \\
\hline \multirow[t]{3}{*}{ R.perezi (L) } & G.M. & 11.2 & 51.1 & 2.6 & 2.9 & 1.6 & 4.5 \\
\hline & Min & 5.2 & 26.2 & 1.0 & 0.6 & 0.3 & 2.0 \\
\hline & Max & 46.0 & 91.4 & 4.9 & 58.1 & 26.7 & 15.6 \\
\hline \multirow[t]{3}{*}{$R$. perezi } & G.M. & 9.3 & 35.4 & 0.5 & 2.7 & 2.4 & 3.8 \\
\hline & Min & 3.0 & 14.6 & 0.1 & 1.1 & 1.0 & 1.6 \\
\hline & Max & 45.6 & 76.4 & 1.8 & 13.9 & 5.5 & 13.1 \\
\hline
\end{tabular}


$2 b$.

\begin{tabular}{|c|c|c|c|c|c|c|}
\hline & & PCBs & DDTs & HCHs & HCB & $\overline{\text { OCS }}$ \\
\hline \multirow[t]{3}{*}{ P.acuta } & G.M. & 1215 & 4619 & 167 & 109 & 43.0 \\
\hline & Min & 616 & 3735 & 70.7 & 56.8 & 0.4 \\
\hline & Max & 2817 & 5646 & 295 & 397 & 849 \\
\hline \multirow[t]{3}{*}{ H.medicinalis } & G.M. & 303 & 1165 & 27.7 & 43.0 & 21.6 \\
\hline & Min & 34.8 & 86.2 & 10.9 & 6.1 & 1.3 \\
\hline & $\operatorname{Max}$ & 711.0 & 3768 & 259 & 257 & 144 \\
\hline \multirow[t]{3}{*}{ Chironomid $(L)$} & G.M. & 805 & 1014 & 131 & 169 & 32.9 \\
\hline & Min & 349 & 285 & 86.8 & 58.2 & 0.2 \\
\hline & Max & 1444 & 2400 & 176 & 718 & 468 \\
\hline \multirow[t]{3}{*}{ H.pistaceus (L) } & G.M. & 1358 & 2137 & 483 & 268 & 3.3 \\
\hline & Min & 454 & 1344 & 76.4 & 124 & 0.2 \\
\hline & $\operatorname{Max}$ & 3003 & 4260 & 1387 & 642 & 57.1 \\
\hline \multirow[t]{3}{*}{ H.pistaceus } & G.M. & 69.0 & 63.2 & 9.1 & 11.4 & 0.9 \\
\hline & Min & 14.5 & 9.9 & 2.4 & 1.5 & 0.1 \\
\hline & $\operatorname{Max}$ & 300 & 206 & 25.4 & 71.0 & 6.1 \\
\hline \multirow[t]{3}{*}{ H.lividus (L) } & G.M. & 264 & 1266 & 39.9 & 28.7 & 19.2 \\
\hline & Min & 110 & 1123 & 23.1 & 13.1 & 6.3 \\
\hline & Max & 911 & 1398 & 84.8 & 57.7 & 79.1 \\
\hline \multirow[t]{3}{*}{ H.lividus } & G.M. & 884 & 1373 & 186 & 67.1 & 1.1 \\
\hline & Min & 90.6 & 234 & 40.1 & 11.11 & 0.1 \\
\hline & Max & 5970 & 67871 & 1395 & 2854 & 617 \\
\hline \multirow[t]{3}{*}{ R.perezi $(L)$} & $\overline{\text { G.M. }}$ & 101 & 462 & 23.3 & 26.4 & 14.1 \\
\hline & Min & 41.2 & 200 & 14.3 & 4.7 & 1.4 \\
\hline & Max & 195 & 1613 & 40.4 & 246 & 113 \\
\hline \multirow[t]{3}{*}{ R. perezi } & G.M. & 105 & 401 & 5.8 & 30.7 & 27.4 \\
\hline & Min & 38.6 & 135 & 0.9 & 10.0 & 13.3 \\
\hline & $\operatorname{Max}$ & 484 & 1251 & 17.1 & 147 & 58.6 \\
\hline
\end{tabular}

